\title{
Record
}

\section{S. S. D. Jones}

Members of the Institute were saddened to learn of the death of Steve Jones on 10 January 1990. His contributions to the life of the Institute and to navigation, both air and marine, were great. One of those rare breed of gentlemen who loved the sea and sailing yet immersed professionally in the world of aviation, Steve contributed much to the research and development of equipment which has stood the test of time.

Educated in Brentwood, he entered the Army direct from University during World War II and joined the Royal Signals, later transferring to the REME. Much of his time during the War was spent in riding a motor cycle around England, selecting sites for searchlights and other installations; a difficult task without the benefit of road signs. A period at the Officer Cadet Training Unit at Aldershot preceded a transfer to RSRE at Malvern, later to become the Royal Radar Establishment. His involvement with radar development for the Army saw his transfer to the Scientific Civil Service. In 1958, a period of three years at the SHAPE Technical Centre in Holland was followed by a move to the Royal Aircraft Establishment at Farnborough, where he joined the Radio Department in 1961 . It was there that he became Superintendent of the Radio Navigation Division and pioneered work upon advanced approach and landing aids for aircraft, long range navigation systems such as Omega and the early experiments upon integrated systems in aircraft.

Always ready to support new ideas, Steve was a great encouragement to members of his team. His usual response was 'Yes. How shall we go about it?'

Steve retired in 1978 and moved with his wife Margaret to Malvern for a spell, but in 1982 they returned to Farnborough to live, when he joined Racal, working much of his time from home.

Steve's interest in the Institute lasted until he died, aged $7 \mathrm{r}$. As a one-time Member of Council and an enthusiastic member of the Technical Committee, he served us well.

Steve Jones leaves Margaret, his three daughters and five grandchildren with proud and fond memories of a most kind and truly professional scientist. We miss him.

Freddy Stringer

\section{STOP PRESS}

\section{RADIO SPECTRUM REVIEW STAGE 2}

The Radio Spectrum Review Committee will shortly examine the future civil and defence frequency allocations between $3400 \mathrm{MHz}$ and $30 \mathrm{GHz}$. The RIN has been invited to submit evidence. Any members who wish to contribute are asked to do so in writing to the Director, RIN, as soon as possible as the response must reach the Review Secretariat by 3 I OCTOBER 1990. 